Additional Perspectives articles for Influenza: The Cutting Edge book collection are available at http://perspectivesinmedicine.cshlp.org/cgi/collection/influenza_the_cutting_edge.

\title{
Original Antigenic Sin: How Original? How Sinful?
}

\author{
Jonathan W. Yewdell and Jefferson J.S. Santos \\ Cellular Biology Section, Laboratory of Viral Diseases, National Institute of Allergy and Infectious Diseases, \\ National Institutes of Health, Bethesda, Maryland 20892, USA \\ Correspondence: jyewdell@niaid.nih.gov
}

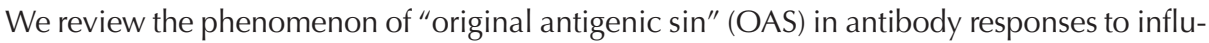
enza A virus (IAV) infection or vaccination. OAS refers to the preferential induction of antibodies with higher affinity to priming versus boosting immunogens. We emphasize its mechanistic basis and origins in the basic immunobiology of B-cell responses to myriad immunogens. We tabulate 23 studies in animals and humans to show that the magnitude of OAS depends on many variables. We discuss a number of misconceptions about OAS, examine the extent to which OAS is sinful, and argue that OAS is evolutionary selected and not a deleterious by-product of selection for other features of the immune response. We end by raising questions regarding the mechanistic basis of OAS whose answers could contribute to improving influenza virus vaccines on the road to the holy grail of a "universal" influenza vaccine.
\end{abstract}

$\mathrm{H}$ uman influenza A virus (IAV) was first isolated in 1933 at Mill Hill in London, by Wilson Smith (from his very own nose, no less), a 35-yr-old MD/virologist, who pioneered growing IAV in embryonated chicken eggs (Evans 1966). Mass human vaccination with formalin-inactivated egg-grown virus began a decade later. Humanity was in for a few surprises. First, even in the 1930s, it became clear that IAV isolates, unlike other viruses or bacterial pathogens known at the time, varied antigenically over time when tested with antisera derived from infected patients or animals. Second, by the mid1940 s, IAV had varied sufficiently to enable it to completely evade protection following vaccination with a 1934 strain. Third, in the early 1950s, it was found that individuals had a strong tendency to possess higher antibody (Ab) titers against IAV strains they were exposed to as children than to more recently circulating strains. Further, on vaccination with contemporary strains, they showed a greater increase in $\mathrm{Ab}$ titers to earlier strains than to the immunizing strain.

This phenomenon, brilliantly dubbed "original antigenic sin" (OAS) by Thomas Francis (Francis 1960), whose laboratory discovered it, has intrigued immunologists and virologists for decades. In no small part, this is because of its very name as well as two elegant immunochemical papers published in the 1960s by Fazekas de St Groth and Rob Webster with the imposing and unforgettable "Disquisitions on Original Antigenic Sin" in their titles (de St Groth and

Editors: Gabriele Neumann and Yoshihiro Kawaoka

Additional Perspectives on Influenza: The Cutting Edge available at www.perspectivesinmedicine.org

Copyright (C) 2021 Cold Spring Harbor Laboratory Press; all rights reserved; doi: 10.1101/cshperspect.a038786

Cite this article as Cold Spring Harb Perspect Med 2021;11:a038786 
J.W. Yewdell and J.J.S. Santos

Webster 1966a,b) (only 19 other papers on PubMed have "disquisition" in the title). In reading these early studies, it is important to recognize that virtually nothing was known about the molecular nature of either Abs or their viral target molecules, the hemagglutinin (HA) and neuraminidase (NA). It is interesting to consider that 50 years from now influenza researchers will (hopefully) read contemporary papers with the same amazement about our insights despite our deep ignorance of how things "really are."

For reasons whose explication should provide employment for scientific historians and social psychologists for decades to come, the medical establishment grew complacent about human influenza viruses after the 1976 swine flu debacle, in which 45 million Americans were immunized against a potential pandemic strain that never became established in humans (although, ironically, the vaccination may have been effective three decades later, when swine-origin IAV did become pandemic). In the decades since, influenza (which include the influenza B viruses, which are only slightly cross-reactive antigenically with IAVs) has exacted a large toll on humanity because of the limited effectiveness of vaccination, which ranges from $10 \%$ to $65 \%$ on a yearly basis. Starting in 1997, the sporadic introduction of highly pathogenic avian IAV strains into human populations reinvigorated interest in IAV and critically in developing a "universal" influenza vaccine, which is now a priority of the United States government. According to the relevant National Institute of Allergy and Infectious Diseases web page (see niaid.nih.gov/diseases-conditions/ universal-influenza-vaccine-research), the universal vaccine should be at least $75 \%$ effective against all human and zoonotic IAV strains for at least $1 \mathrm{yr}$ following immunization in all age groups.

Developing such a vaccine is likely to require better understanding of the protective immune response to IAV, which in turn, will require a better understanding of OAS. The rekindled interest in OAS is reflected in the publication of at least 10 fine reviews in the past few years that deal with OAS in some detail, which the reader is encouraged to peruse
(Cobey and Hensley 2017; Monto et al. 2017; Vatti et al. 2017; Henry et al. 2018; Lewnard and Cobey 2018; Devarajan and Swain 2019; Francis et al. 2019; Krammer 2019; Zhang et al. 2019; Zost et al. 2019).

Here, we emphasize immunological mechanistic aspects of the OAS phenomenon that have not been covered in detail by the previous reviews, discuss the evolutionary significance of OAS as a basic feature of the immune response, and identify critical questions for future research.

\section{OAS MISCONCEPTIONS}

An important problem in understanding OAS is its inconsistent use by different investigators. Here, we adhere to Francis's original definition: the induction of a more robust immune response to the priming "versus" a boosting immunogen that itself binds poorly, if at all, to Abs induced by the priming immunogen (Francis 1960). In an instructive example, the classic study of responses to the swine flu vaccine in 1978 (A/NJ/8/76; H1N1), individuals on average responded much more vigorously to the vaccine strain than to other $\mathrm{H} 1$ strains tested (including $\mathrm{A} / \mathrm{PR} / 8 / 34, \mathrm{H} 1 \mathrm{~N} 1$ [PR8], which is fairly closely related to $\mathrm{A} / \mathrm{NJ} / 8 / 76$ ) among all age groups tested (Noble et al. 1977). Based, however, on the clear (but lower) response to early $\mathrm{H} 1$ viruses, these investigators concluded that the vaccine induced an OAS response.

In part because of confusion about what constitutes OAS, misconceptions about OAS are common in the literature and among practicing viral immunologists and vaccinologists.

\section{Misconception: OAS Is a Constant Feature of IAV Immunity}

OAS is a robust phenomenon that has been observed in many clinical studies and is highly reproducible in animal models under controlled conditions. In Table 1, we summarize results from 16 studies in humans and in Table 2, nine studies in animal models. Altogether, OAS is observed in only about one-half of the studies. 
Original Antigenic Sin

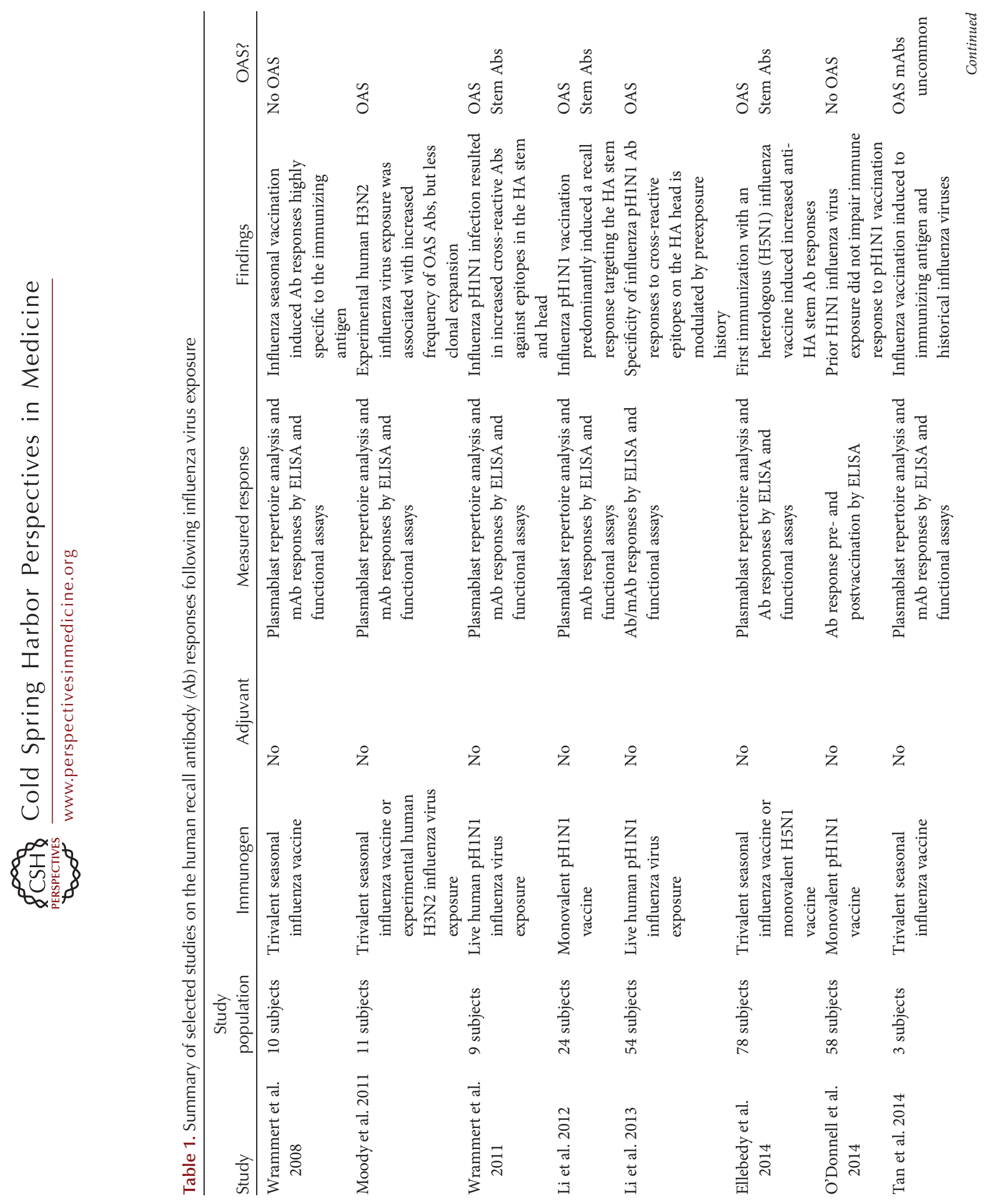


J.W. Yewdell and J.J.S. Santos
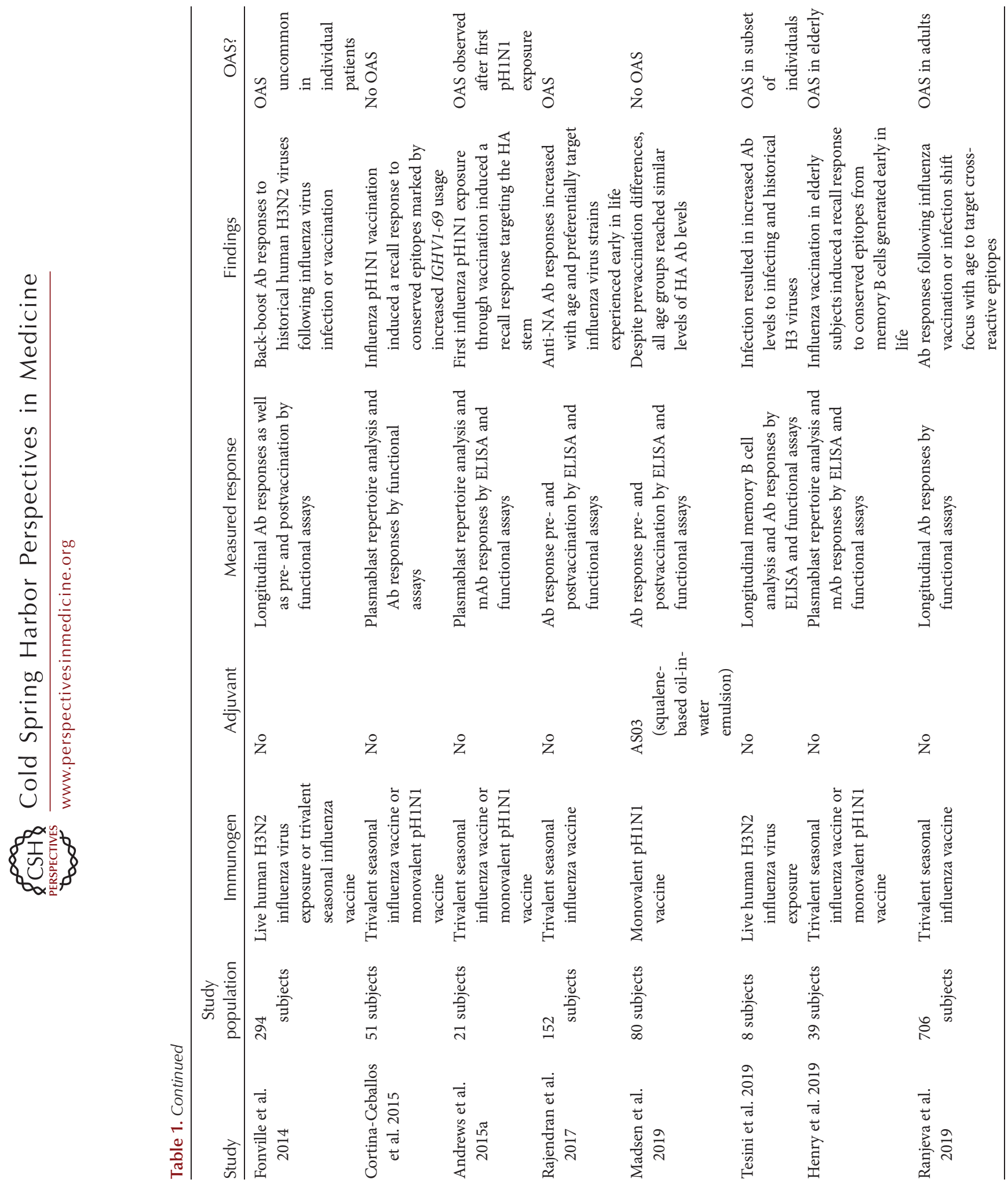
Original Antigenic Sin
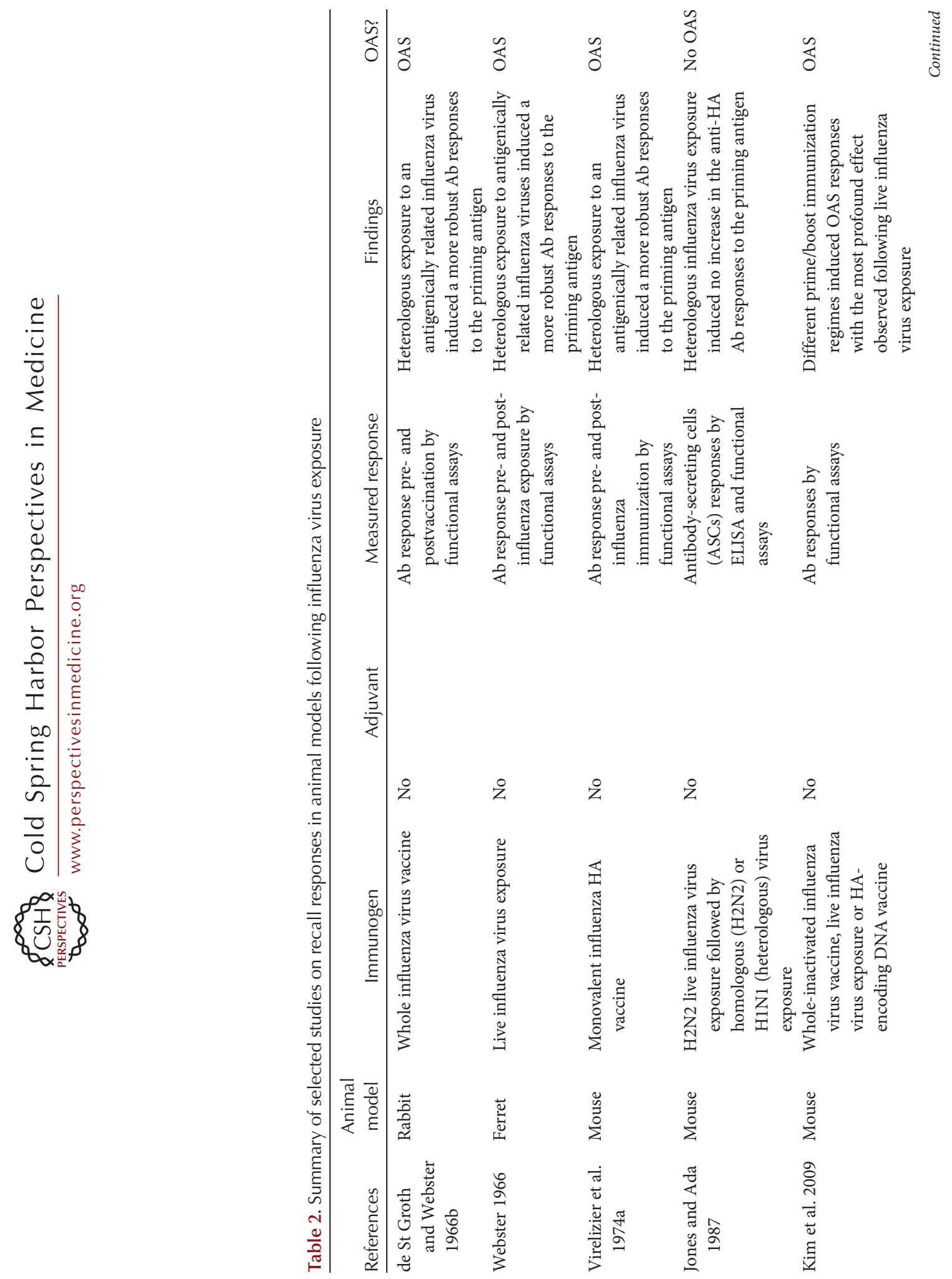
J.W. Yewdell and J.J.S. Santos
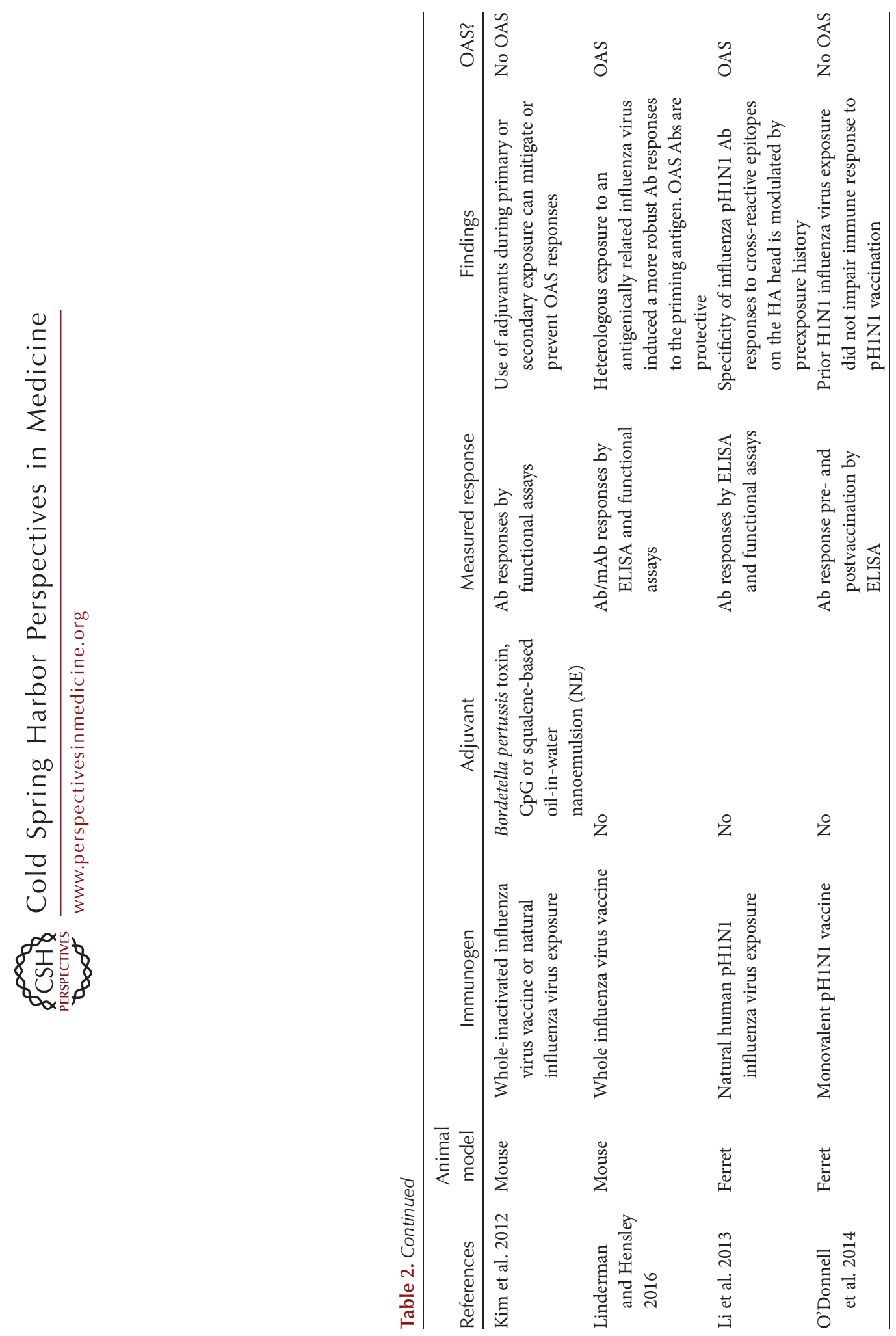
Of particular note is the Fonville et al. (2014) "antibody landscape" study. Serum samples collected yearly for 6 years from 69 individuals were tested in hemagglutination inhibition (HI) assays for Abs that block viral attachment to host cells against 30 epidemic $\mathrm{H} 3 \mathrm{~N} 2$ viruses collected over a 41-yr period. Twelve of the individuals experienced laboratory-confirmed natural H3N2 infection, whereas 26 others were likely infected based on a large increase in serum $\mathrm{Ab}$ titers. There was enormous variability in the duration and induction of OAS Abs between individuals in an age-independent manner. Infection typically induced Abs to both contemporary and older strains, with only few individuals showing a strong OAS effect. At the same time, within several years postinfection, and often within a year, $\mathrm{Ab}$ titers to boosting strains typically waned, whereas response to older strains was maintained.

Fonville et al. (2014) also measured hemagglutination inhibiting (HI) Abs against the same panel of $\mathrm{H} 3 \mathrm{~N} 2$ viruses pre- and postimmunization in more than 100 patients in two vaccine trials with different seasonal vaccines. As with natural infection, there was enormous variation in the induction of OAS, which, on average, was not the predominant response.

In digesting and comparing information from various OAS studies, it is critical to consider the details.

What is the form of immunogen used for priming and boosting? Boosting with whole virus or infectious virus (which will generate whole virus or infected cell fragments with many HA copies) presents multivalent immunogens to B cells that favor activating B cells with Abs that bind to the boosting immunogen with low affinity. Boosting with infectious virus, however, will be modulated, sometimes extremely, by preexisting Abs, and possibly by cellular immune mechanisms as well, that limit viral replication and proportionally decrease the dose of boosting immunogen presented to the immune system. In general, limiting the amount of immunogen greatly exacerbates OAS, as the boosting antigen is sequestered by B cells specific for the priming immunogen. For experimental purposes to mechanistically dissect OAS (and per- haps, eventually, human vaccines), the influence of preexisting antibodies on the boosting immune response can be minimized by DNA/ RNA immunization (Kim et al. 2009).

How are Ab responses measured? Anti-HA serum Abs from challenged individuals have been historically measured largely by functional assays-namely, hemagglutination inhibition and in vitro virus neutralization (VN), which are biased by the functional activities of antibodies specific for different HA regions. Abs specific for antigenic sites near the receptor binding site (RBS) typically show higher activities in these assays (i.e., they provide greater inhibition per occupancy) than those further down the HA spike (Angeletti et al. 2017), with Abs against the stem region showing no HI activity and limited VN activity in standard assays.

Such assays will therefore skew analysis toward Abs that bind the globular domain, and particularly Abs that show the highest functional activities, greatly underestimating Abs specific for the HA stem, as well as Abs whose epitopes are not exposed on native HA, rendering them invisible in functional assays. This factor is important in comparing findings from different OAS studies, as some studies, including the classical "Disquisitions" papers (de St Groth and Webster 1966a,b) and the original B-T-cell mechanistic studies of Virelizier et al. (1974a, b), were based on Ab binding assays. Direct $\mathrm{Ab}$ binding studies are much to be preferred in dissecting OAS mechanistically because they provide the most direct and comprehensive measure of anti-HA B cell responses. Further, it is becoming clear that Abs with weak or nondetectable HI or $\mathrm{VN}$ activities in vitro, including Abs specific for the stem or cryptic epitopes exposed by HA breathing (Yewdell et al. 1993; Watanabe et al. 2019), can exert antiviral activity in vivo via Fcreceptor $(\mathrm{FcR})$-based innate cellular immunity (DiLillo et al. 2016; He et al. 2016).

Data presentation can be critical in interpreting the magnitude and biological significance of OAS. HI and VN data are typically presented as logarithmic values. All things being equal, a twofold increase of a titer of $1 / 1000$ represents a greater increase in Ab concentration than does a 10 -fold increase in a starting 
J.W. Yewdell and J.J.S. Santos

titer of $1 / 100$. As twofold increases in HI and $\mathrm{VN}$ assays are often considered nonsignificant based on statistical analyses, this can skew interpretation of immune responses. Using more precise assays for $\mathrm{Ab}$ inhibition of attachment and infection in the form of plate-based attachment assays (using viral NA as a self-reporter) (Kosik and Yewdell 2017) and flow-based neutralization assays with fluorescent reporter IAVs (Kosik et al. 2019) would represent a major improvement in analyzing immunity to flu and with adaptations, other viruses as well.

\section{Misconception: OAS Is Limited to Viruses within the Same Subtype}

The recent recognition that $\mathrm{HA}$ stem-specific and, to a lesser extent, head-specific Abs can cross-react between subtypes within a group (and even between groups) has opened a new horizon in the OAS phenomenon (although there have been reports of unexplained crossreactive Abs, including $\mathrm{H} 2$ and $\mathrm{H} 3 \mathrm{HI}+\mathrm{Abs}$ induced by vaccination with inactivated whole H1 virus [Noble et al. 1977]).

Inter-HA subgroup OAS appears to be of great importance in human "natural" protection against highly pathogenic zoonotic viruses. Gostic et al. (2016) reported that the severity and lethality of avian H5 and H7 virus infections are heavily biased by patient exposure history. Individuals first exposed as children to group 1 $\mathrm{HA}(\mathrm{H} 1$ or $\mathrm{H} 2)$ human viruses were preferentially protected against lethality from an avian group $1 \mathrm{HA}$ virus (H5), whereas those initially exposed to a human group $2 \mathrm{HA}$ virus (H3) were protected from an avian group 2 (H7) virus. Lifelong HA/NA subtype-specific susceptibility to severe infection resulting from first exposure(s) to viruses of the opposite subtype also appears to extend to $\mathrm{H} 1 \mathrm{~N} 1$ and $\mathrm{H} 3 \mathrm{~N} 2$ viruses (Arevalo et al. 2019; Gostic et al. 2019).

\section{Misconception: OAS Generates Nonfunctional Abs}

Many biologists conceive of $\mathrm{Ab}$ binding as a quantal event: Either an Ab binds an antigen or it does not. But interactions between sub- stances are always scalar: At some level, every Ab binds every antigen, just with different affinity (or avidity for multivalent ligands). Primary antibodies induced by HA typically have dissociation constants $\left(\mathrm{K}_{\mathrm{D}}\right)$ in the 1 to $10 \mathrm{nM}$ range, increasing up to 100-fold after multiple rounds of somatic mutation induced by boosting (de St Groth and Webster 1966a,b; Webster 1966; Frank et al. 2015; Angeletti et al. 2019). Ab affinity for cross-reacting antigens will generally be lower than inducing immunogens, but even low-affinity interactions become meaningful at high concentrations of just one of the reactants. The binding of Abs with a $\mathrm{K}_{\mathrm{D}}>0.1 \mu \mathrm{M}$ will likely not be detected in ELISA assays because of dissociation during the secondary labeling step. Such Abs will bind 50\% of HAs, however, at a concentration of $0.1 \mu \mathrm{M}$, which is $15 \mu \mathrm{g} / \mathrm{mL}$. For comparison's sake, the amount of Ab present in human serum specific for circulating strains is between 0.1 and $1 \mathrm{mg} / \mathrm{mL}$ (de St Groth and Webster 1966a), clearly sufficient for binding to "weakly" cross-reacting antigens.

Thus, it is entirely possible that OAS Abs that "do not bind" to challenge antigens based on overinterpreting in vitro assays can show biological activity in vivo. Complicating matters, the relationship between $\mathrm{Ab}$ virus in vitro neutralizing activity does not linearly predict in vivo protection or treatment activity. This is obviously true for stem binding Abs but even extends to head-specific Abs that block virus attachment (Mozdzanowska et al. 1997).

The induction of "nonbinding" OAS Abs is clearest at the level of monoclonal Abs (mAbs). This was first described by Gerhard (1978), who characterized mAbs secreted over a 30- to $40 \mathrm{~d}$ period by individual B-cell clones present in splenic fragments from irradiated mice that received limiting amounts of B cell from immunized mice (Klinman 1972). Gerhard reported that $70 \%$ of B cells stimulated in vitro with a 1946 strain produced mAbs that would not detectably bind (in a plate-based indirect radioimmunoassay) the 1934 strain used to prime the $\mathrm{B}$ cells. Importantly, in this splenic fragment system, activation of secondary B cells with priming virus required 100-fold less virus than activation of naive B cells (Braciale et al. 1976). This 
strongly implies the enhanced sensitivity of secondary B cells and accounts for their triggering by low-avidity antigens, underlying the OAS phenomenon.

This pioneering study was revisited by Linderman and Hensley (Linderman et al. 2014), who used a defined drift variant, S12a, that had been selected by sequential neutralization with 12 mouse mAbs to generate a large panel of new mAbs from mice immunized with PR8 and boosted with S12a. S12a differs from PR8 by 13 amino acids distributed among the five antigenic sites present in the $\mathrm{H} 1$ globular domain. This represents $\sim 8 \mathrm{yr}$ of typical antigenic drift in human $\mathrm{H} 1$ isolates. Using the standard measure of OAS, the HI assay, and also ELISAs to include Abs specific for epitopes distant from the RBS, they found that PR8 priming with S12a boosting recapitulated the classic findings of other animal studies. Boosting with inactivated virus at a dose similar to that typically used for human vaccination (note that immunogen does not scale with organism mass due to the nature of lymph drainage and delivery to lymph nodes) induced secondary Abs specific for the priming immunogen and primary Abs for the boosting immunogen. Importantly, adoptively transferred serum Abs induced by PR8-S12a immunization protected against S12a infectious challenge.

As expected, in ELISAs, the vast majority of PR8-elicited primary mAbs bound PR8 but not S12a, and $\sim 90 \%$ of PR8 prime PR8 boosted mAbs were PR8-specific, with the rest cross-reacting strongly with S12a. After PR8 priming and S12a boosting, $55 \%$ of $\mathrm{mAbs}$ were of the OAS phenotype in binding PR8 but not S12. Importantly, antigenic mapping of the mAbs, using a large panel of PR8 escape mutants with single amino acid substitutions covering the five major antigenic sites, revealed that the distribution of OAS Abs for binding to different antigenic sites was similar between OAS phenotype $\mathrm{mAbs}$ and PR8 specific mAbs, with Sb-site specific Abs dominating. Sequencing of several clonally related $\mathrm{Sb}$-specific $\mathrm{mAbs}$ revealed that only a few amino acid substitutions in the heavy chain were required to increase binding to S12a by 20 -fold.
Critically, protection experiments revealed that a mAb scored as S12a-"nonbinding" in a standard ELISA can protect mice against S12a infection as effectively as a mAb induced by S12a primary infection. As cautioned above, nonbinding is an operational term, and indeed, using higher concentrations of Abs, it was determined that the nonbinding $\mathrm{Ab}$ binds to $\mathrm{S} 12 \mathrm{a}$, but at $\sim 200$-fold lower avidity than to PR8 $\left(K_{D}\right.$ of $600 \mathrm{nM}$ vs. $2 \mathrm{nM}$ ).

This important study hammers home the message that OAS phenotype Abs induced by vaccination can be biologically important on their own, and further, that under many circumstances they will be accompanied by primary Abs induced by the vaccine that will also be protective. At the same time, it is important to consider that there is solid evidence in animal models (Kim et al. 2009), and indeed in man (Gostic et al. 2016, 2019; Arevalo et al. 2019), that priming can weaken protection afforded by subsequent infection/vaccination with other IAVs.

\section{Misconception: OAS Is Inevitable}

First, as shown in Table 1, OAS was weak or absent in many studies and, as strikingly shown by Fonville et al. (2014) (the supplemental figures are well worth perusing), varies enormously among vaccinated or infected individuals.

Second, in the second Disquisition paper, Webster and Fazekas showed that increasing the dose of boosting virus in rabbits increased the relative $\mathrm{Ab}$ response to the boosting versus the priming virus. Increasing vaccine dose in humans had a similar effect (Webster et al. 1976). OAS is also mitigated in mice by multiple booster immunizations (Kim et al. 2012). This mechanism almost certainly contributes to the common finding that OAS is most extreme when conditions are such that boosting with infectious virus generates an infection that generates a limited amount of virus.

Third, Kim and colleagues found that including an adjuvant (including one similar to that used for human influenza vaccination) during either priming or boosting mice can mitigate 
J.W. Yewdell and J.J.S. Santos

OAS by increasing Abs to the boosting virus without decreasing the OAS Ab response.

\section{Misconception: OAS Is a Peculiarity of Antiviral Immunity and Is Mechanistically Undefined}

OAS has been described for at least four different virus groups: orthomyxoviruses (IAV), flaviviruses (dengue, zika), retroviruses (HIV), and picornaviruses (enterovirus) (Vatti et al. 2017). But the phenomenon is not limited to viruses. Remarkably, the general phenomenon of OAS in $\mathrm{Ab}$ responses to related immunogens was first reported in 1910 when Dreyer and Walker (1910) found that boosting rabbits primed with Escherichia coli with Staphylococcus aureus elicited a robust $E$. coli Ab response. Similar findings with antibacterial $\mathrm{Ab}$ responses were reported in several subsequent publications (see Dixon et al. 1954, for references).

Just a year after Davenport et al. (1953), Dixon et al. (1954) reported that after priming rabbits with bovine serum albumin (BSA), boosting with human serum albumin (HSA), which shares $75 \%$ sequence homology with BSA, results in an immediate (within $1 \mathrm{~d}$ ) robust anti$\mathrm{BSA} \mathrm{Ab}$ response that is not cross-reactive with HSA. Cross-reactive and HSA-specific Abs begin to appear $6 \mathrm{~d}$ after boosting, with specific Abs at one-half the levels of cross-reactive Abs. (Interestingly, $\mathrm{Ab}$ responses were measured in absolute values, generally in the range of 100 to $500 \mu \mathrm{g} / \mathrm{mL}$, or 0.67 to $3.3 \mu \mathrm{M}$. Such absolute quantitation of $\mathrm{Ab}$ responses, which was standard in the field, was somehow lost in the 1970s, to the detriment of science.)

Extending the OAS phenomenon to the haptens DNP and TNP (bound to a carrier protein), Eisen et al. (1969) showed via serum Abs that TNP can activate DNP-primed B cells that do not respond to TNP priming, and vice versa. Similarly, at the level of single antibody-secreting B cells detected via the Jerne plaque assay (Jerne and Nordin 1963), Deutsch and colleagues showed an extremely robust OAS response to a different hapten pair (Deutsch and Bussard 1972; Deutsch et al. 1973). Using isoelectric focusing to separate abundant oligo/monoclonal serum Abs that bind radiolabeled antigens, Cramer and Braun (1973) showed that vaccination with a heat-killed whole cell group A streptococcal vaccine elicited a strong secondary $\mathrm{Ab}$ response to a mutant strain with a distinct cell wall polysaccharide that would only detectably bind the priming polysaccharide.

The nature of OAS Abs at the level of $A b$ sequences was first characterized by Fish et al. (1989), who studied Ab responses to the Ars hapten in a mouse strain generating Abs encoded by a dominant single Vh gene segment. Immunization with sulfated Ars (Sulf) did elicit Abs with this Vh segement unless B cells were primed by Ars. The affinities of Sulf-elicited OAS Abs were, with few exceptions, 10-fold to $>200$-fold lower to Sulf versus Ars. This is too weak to activate naive $\mathrm{B}$ cells, explaining Sulf's low immunogenicity in primary responses. Notably, Sulf is able to activate only a small fraction of Ars memory cells, likely those with somatic mutations that increase Sulf binding.

To summarize, we know the following.

1. OAS is a universal phenomenon that reflects the basic working of the immune system in mice, rabbits, ferrets, humans, and likely most, if not all, jawed vertebrates (and perhaps jawless vertebrates as well [Altman et al. 2015]).

2. OAS is based on memory B cells being triggered by much lower antigen concentrations than naive B cells. Consequently, memory B cells are triggered by weakly cross-reacting immunogens to produce OAS Abs. This mechanism was first inferred by de St Groth and Webster (1966b) based on the rapid increase in OAS Abs and resistance to $\gamma$ irradiation, both typical of memory $\mathrm{Ab}$ responses.

3. OAS is exacerbated by boosting with limited amounts of immunogens, because memory B cells sequester the immunogens compromising the activation of naive $B$ cells, despite the latter having higher affinity Abs for the immunogen. 
4. Although OAS Abs have low avidity for their activating immunogen, they still can exert antiviral activity if present at high enough concentrations.

\section{IS OAS A BUG ? A FEATURE? BOTH?}

The universality of OAS in B-cell immunity begs the question of its evolution. There is no apparent reason a priori that secondary B cells should be triggered by lower-affinity antigens than primary B cells. The increase in B-cell precursors in creating the memory B-cell pool alone would confer a memory phenotype. For invariant natural immunogens, the high sensitivity of secondary B cells that underlies OAS would seem to provide obvious advantages, as in most cases it would generate a rapid boost in effective Abs to proven dangerous non-self immunogen. A contributing factor to the evolution of hair-triggered-memory B cells may be the presence of Abs that reduce the effective dose of immunogens available for triggering.

If advantages conferred by highly sensitive triggering of memory B cells is the primary selection pressure for OAS, then its negative effects on B cells responses to antigenically variant viruses could be an unavoidable and acceptable cost. But are OAS Abs deleterious? As discussed above, low-avidity Abs can be effective in vivo. If so, their rapid increase as occurs in OAS might confer major evolutionary benefits. OAS may be particularly beneficial for protection against viruses with multiple cocirculating serotypes (e.g., rhinoviruses that were not selected based on contemporary immune escape). It is also important to remember that under most conditions, a typical primary response to the OAS challenge immunogen occurs in the face of the rapid increase in OAS Abs-in other words, a win-win scenario.

At the same time, the recent findings of Gostic et al. (2016) strongly imply that initial exposure to a given IAV incurs a lifelong cost in decreasing protection from severe infection against viruses with HAs from different groups. This is very likely to be based on B-cell responses, as T-cell responses are far more cross-reactive between IAV gene products, including the gly- coproteins (although somewhat less cross-reactive than the internal proteins, which are far less variable).

Better accounting for the costs and benefits of OAS will require deeper understanding of basic immunological mechanisms underlying OAS including B-cell signaling, T-cell help, and accessory cell function, as well as carefully measuring the protective value of low-avidity Abs primed by cross-reactive immunogens. The success of cancer immunotherapy after decades of skepticism about the relevance of tumor immunosurveillance provides a shining example of the benefits of systematic and methodical investigation of basic immune mechanisms.

\section{CONCLUSION: WHAT DO WE NEED TO KNOW ABOUT OAS?}

A number of critical questions need to be addressed regarding the immunobiology and clinical relevance of OAS.

How do preexisting Abs affect OAS? By definition, OAS occurs in the presence of preexisting Abs. In mice, mAb Fabs and polyclonal Abs can selectively suppress memory responses to their cognate antigenic site, in the latter case, despite the presence of memory B cells derived from the primary responding $\mathrm{B}$ cells that produce the Abs (Angeletti et al. 2017). Thus, Abs can reverse the OAS phenomenon (original antigenic suppression), even overcoming the normal advantages of memory versus primary B cells in responding to challenge. Ab-mediated suppression appears to occur in humans, in whom higher $\mathrm{Ab}$ titers correlate with lower vaccine responses (Sasaki et al. 2008; Fonville et al. 2014). It also may contribute to the observation that human $\mathrm{Ab}$ titers are higher to strains in trivalent vaccines that have varied the most over the years of repeated vaccination (and natural exposure) (Andrews et al. 2015b; Skowronski et al. 2017).

Central to understanding anti-IAV Ab function is a detailed characterization of the composition of Abs in body fluids. Remarkable progress has been made in mass spectrometricbased detection and quantitation of affinity-pu- 
rified Abs (Georgiou et al. 2014). In an astonishing study of the anti-IAV Ab repertoire of a single 57-yr-old (to start) patient, Lee et al. (2019) found that over a 5-yr period a single Ab species constituted $\sim 20 \%$ of all Abs against a circulating strain, reaching $50 \%$ immediately after vaccination. Twenty-four Abs accounted for $65 \%-85 \%$ of the repertoire at any one time. The pauci-clonal nature of the response, despite repeated vaccination, raises many questions, including how common is this limited repertoire among different age groups, how can the immune system be persuaded to recruit new Bcell clones, and, not least, does this enable immune escape and account for antigenic drift?

How do adjuvants modulate OAS? Adjuvants are well known to enhance $\mathrm{Ab}$ responses to influenza vaccines resulting from myriad alterations in numerous innate and adaptive cells. Kim et al.'s (2012) findings show that in mice adjuvants can mitigate OAS both at the priming and boosting stages. The priming effect suggests a major role for Th cells in the phenomenon. This can be tested by adoptive transfer experiments with purified $\mathrm{B}$ and $\mathrm{CD} 4^{+} \mathrm{T}$-cell populations, and possibly $\mathrm{CD} 4^{+} \mathrm{T}$ cell-clones/lines/ TCR transgenic cells. Kim and colleagues observed that although three adjuvants tested overrode OAS in secondary responses, one of the three failed in primary responses, providing another jumping-off point for additional experiments. To relate these findings to humans, it should be possible to compare OAS Ab responses in samples from some of the many clinical trials establishing the efficacy of adjuvanted vaccines. Indeed, Madsen et al. (2019) recently reported that adjuvanted human vaccination failed to induce OAS Abs.

How important are weakly binding Abs in influenza immunity? The protective effect of such Abs is well established in mice (Linderman et al. 2014), but difficult to address in humans. In flavivirus infections, such Abs are well established to be harmful, based on enhancing infection of FcR-bearing cells. In IAV, there is no evidence for this effect, consistent with the limited ability of IAV to replicate in nonrespiratory epithelial cells. Protective effects might be inferred from correlating clinical outcomes on an individual patient basis using Ab landscapes (Fonville et al. 2014). This question is ultimately intimately linked with the larger issue of how anti-HA Abs protect against human IAV, breaking down the relative contributions of blocking viral attachment, fusion, release, and enhancing FcR-based innate cellular antiviral mechanisms.

How important is imprinting in IAV pathogenesis and how can it be modulated? Epidemiological studies clearly show that initial exposure to IAV improves the clinical outcome decades in the future to infection with strains that possess HA from the same group (Gostic et al. 2016, 2019; Arevalo et al. 2019). To what extent is this a positive effect on homotypic immunity versus a negative effect on heterotypic immunity and are there any effects on infection with influenza B viruses or even more distantly related viruses? Is the group-specific nature of imprinting due to priming of HA stem-specific B cells (Tesini et al. 2019)? If so, can it be overcome by immunogens designed to activate only B cells specific for the nonimprinted stem or avoided entirely by including group I and group II immunogens in the first vaccine a child receives (perhaps, immunizing with each immunogen in different sites to avoid competition in individual lymph nodes [Angeletti et al. 2019]).

Why is it so difficult to generate durable $A b$ responses to drifted viruses in a sizable fraction of the population after vaccination or even infection? Fonville et al. (2014) observed this in a large number of individuals of all ages, pointing to a defect in generating long-lived bone marrow plasma cells, which are the principal source of durable serum $\mathrm{Ab}$ responses. This likely is a major factor in IAV vaccine ineffectiveness. Because noninfluenza vaccines, with few exceptions, generate durable responses in a high fraction of individuals over many age groups, it appears that immunological memory interferes with this process. A critical question is the extent to which this is specific for IAV or rather, as seems much more likely, generally occurs with closely related immunogens. This may be the true sin in OAS and is ripe for testing in animal models, which could provide essential insight regarding the underlying mechanism and how it might be overcome in humans. 


\section{ACKNOWLEDGMENTS}

The authors are supported by the Division of Intramural Research, National Institute of Allergy and Infectious Diseases, Bethesda, MD.

This article has been made freely available online courtesy of TAUNS Laboratories.

\section{REFERENCES}

Altman MO, Bennink JR, Yewdell JW, Herrin BR. 2015. Lamprey VLRB response to influenza virus supports universal rules of immunogenicity and antigenicity. eLife 4: e07467. doi:10.7554/eLife.07467

Andrews SF, Huang Y, Kaur K, Popova LI, Ho IY, Pauli NT, Henry Dunand CJ, Taylor WM, Lim S, Huang M, et al. 2015a. Immune history profoundly affects broadly protective B cell responses to influenza. Sci Transl Med 7: 316ra192. doi:10.1126/scitranslmed.aad0522

Andrews SF, Kaur K, Pauli NT, Huang M, Huang Y, Wilson PC. 2015b. High preexisting serological antibody levels correlate with diversification of the influenza vaccine response. J Virol 89: 3308-3317. doi:10.1128/JVI.02871-14

Angeletti D, Gibbs JS, Angel M, Kosik I, Hickman HD Frank GM, Das SR, Wheatley AK, Prabhakaran M, Leggat DJ, et al. 2017. Defining B cell immunodominance to viruses. Nat immunol 18: 456-463. doi:10.1038/ni.3680

Angeletti D, Kosik I, Santos JJS, Yewdell WT, Boudreau CM, Mallajosyula VVA, Mankowski MC, Chambers M, Prabhakaran M, Hickman HD, et al. 2019. Outflanking immunodominance to target subdominant broadly neutralizing epitopes. Proc Natl Acad Sci 116: 13474-13479. doi:10.1073/pnas.1816300116

Arevalo P, McLean HQ, Belongia EA, Cobey S. 2019. Earliest infections predict the age distribution of seasonal influenza A cases. medRxiv 19001875.

Braciale TJ, Gerhard W, Klinman NR. 1976. Analysis of the humoral immune response to influenza virus in vitro. J Immunol 116: 827-834.

Cobey S, Hensley SE. 2017. Immune history and influenza virus susceptibility. Curr Opin Virol 22: 105-111. doi:10 $.1016 /$ j.coviro.2016.12.004

Cortina-Ceballos B, Godoy-Lozano EE, Téllez-Sosa J, Ovilla-Muñoz M, Sámano-Sánchez H, Aguilar-Salgado A, Gómez-Barreto RE, Valdovinos-Torres H, LópezMartinez I, Aparicio-Antonio R, et al. 2015. Longitudinal analysis of the peripheral $B$ cell repertoire reveals unique effects of immunization with a new influenza virus strain. Genome Med 7: 124. doi:10.1186/s13073-015-0239-y

Cramer M, Braun DG. 1973. Cross-stimulation of monoclonal antibodies in anamnestic responses. J Exp Med 138: 1533-1544. doi:10.1084/jem.138.6.1533

Davenport FM, Hennessy AV, Francis T Jr, with the technical assistance of Phyllis Fabisch. 1953. Epidemiologic and immunologic significance of age distribution of antibody to antigenic variants of influenza virus. J Exp Med 98: 641-656. doi:10.1084/jem.98.6.641

de St Groth SF, Webster RG. 1966a. Disquisitions on original antigenic sin. I: evidence in man. J Exp Med 124: 331-345. doi:10.1084/jem.124.3.331 de St Groth SF, Webster RG. 1966b. Disquisitions on original antigenic sin. II: proof in lower creatures. J Exp Med 124: 347-361. doi:10.1084/jem.124.3.347

Deutsch S, Bussard AE. 1972. Original antigenic sin at the cellular level. I: antibodies produced by individual cells against cross-reacting haptens. Eur J Immunol 2: 374378. doi:10.1002/eji.1830020416

Deutsch S, Vinit MA, Bussard AE. 1973. Original antigenic sin at the cellular level. II: specificity of the antibodies produced by individual cells. Eur J Immunol 3: 235240. doi:10.1002/eji.1830030411

Devarajan P, Swain SL. 2019. Original antigenic sin: friend or foe in developing a broadly cross-reactive vaccine to influenza? Cell Host Microbe 25: 354-355. doi:10.1016/j .chom.2019.02.009

DiLillo DJ, Palese P, Wilson PC, Ravetch JV. 2016. Broadly neutralizing anti-influenza antibodies require $\mathrm{Fc}$ receptor engagement for in vivo protection. J Clin Invest 126: 605610. doi:10.1172/JCI84428

Dixon FJ, Maurer PH, Deichmiller MP. 1954. Primary and specific anamnestic antibody responses of rabbits to heterologous serum protein antigens. J Immunol 72: 179186.

Dreyer G, Walker EWA. 1910. Observations on the production of immune substances. J Pathol Bacteriol 14: 28-38. doi:10.1002/path.1700140103

Eisen HN, Little JR, Steiner LA, Simms ES, Gray W. 1969. Degeneracy in the secondary immune response: stimulation of antibody formation by cross-reacting antigens. Isr J Med Sci 5: 338-351.

Ellebedy AH, Krammer F, Li GM, Miller MS, Chiu C, Wrammert J, Chang CY, Davis CW, McCausland M, Elbein R, et al. 2014. Induction of broadly cross-reactive antibody responses to the influenza HA stem region following H5N1 vaccination in humans. Proc Natl Acad Sci 111: 1313313138. doi:10.1073/pnas.1414070111

Evans DG. 1966. Wilson Smith, 1897-1965. Biogr Mem Fellows $R$ Soc 12: 478-487. doi:10.1098/rsbm.1966.0023

Fish S, Zenowich E, Fleming M, Manser T. 1989. Molecular analysis of original antigenic sin. I: clonal selection, somatic mutation, and isotype switching during a memory B cell response. J Exp Med 170: 1191-1209. doi:10.1084/ jem.170.4.1191

Fonville JM, Wilks SH, James SL, Fox A, Ventresca M, Aban M, Xue L, Jones TC, Le NMH, Pham QT, et al. 2014. Antibody landscapes after influenza virus infection or vaccination. Science 346: 996-1000. doi:10.1126/science .1256427

Francis T Jr. 1960. On the doctrine of original antigenic sin. Proc Am Philos Soc 104: 572-578.

Francis ME, King ML, Kelvin AA. 2019. Back to the future for influenza preimmunity-looking back at influenza virus history to infer the outcome of future infections. $\mathrm{Vi}$ ruses 11: 122. doi:10.3390/v11020122

Frank GM, Angeletti D, Ince WL, Gibbs JS, Khurana S, Wheatley AK, Max EE, McDermott AB, Golding H, Stevens J, et al. 2015. A simple flow-cytometric method measuring $B$ cell surface immunoglobulin avidity enables characterization of affinity maturation to influenza A virus. mBio 6: e01156. doi:10.1128/mBio.01156-15 
J.W. Yewdell and J.J.S. Santos

Georgiou G, Ippolito GC, Beausang J, Busse CE, Wardemann H, Quake SR. 2014. The promise and challenge of high-throughput sequencing of the antibody repertoire. Nat Biotech 32: 158-168. doi:10.1038/nbt.2782

Gerhard W. 1978. The analysis of the monoclonal immune response to influenza virus. III: the relationship between stimulation of virus-primed precursor B cells by heterologous viruses and reactivity of secreted antibodies. J Immunol 120: 1164-1168.

Gostic KM, Ambrose M, Worobey M, Lloyd-Smith JO. 2016. Potent protection against $\mathrm{H} 5 \mathrm{~N} 1$ and H7N9 influenza via childhood hemagglutinin imprinting. Science 354: 722 726. doi:10.1126/science.aag1322

Gostic KM, Bridge R, Brady S, Viboud C, Worobey M, Lloyd-Smith JO. 2019. Childhood immune imprinting to influenza A shapes birth year-specific risk during seasonal H1N1 and H3N2 epidemics. PLoS Pathog 354: e1008109.

He W, Tan GS, Mullarkey CE, Lee AJ, Lam MM, Krammer F, Henry C, Wilson PC, Ashkar AA, Palese P, et al. 2016. Epitope specificity plays a critical role in regulating antibody-dependent cell-mediated cytotoxicity against influenza A virus. Proc Natl Acad Sci 113: 11931-11936. doi:10 $.1073 /$ pnas.1609316113

Henry C, Palm AE, Krammer F, Wilson PC. 2018. From original antigenic sin to the universal influenza virus vaccine. Trends Immunol 39: 70-79. doi:10.1016/j.it.2017.08 .003

Henry C, Zheng NY, Huang M, Cabanov A, Rojas KT, Kaur K, Andrews SF, Palm AE, Chen YQ, Li Y, et al. 2019. Influenza virus vaccination elicits poorly adapted B cell responses in elderly individuals. Cell Host Microbe 25: 357-366.e6. doi:10.1016/j.chom.2019.01.002

Jerne NK, Nordin AA. 1963. Plaque formation in agar by single antibody-producing cells. Science 140: 405. doi:10 $.1126 /$ science.140.3565.405

Jones PD, Ada GL. 1987. Persistence of influenza virus-specific antibody-secreting cells and B-cell memory after primary murine influenza virus infection. Cell Immunol 109: 53-64. doi:10.1016/0008-8749(87)90291-7

Kim JH, Skountzou I, Compans R, Jacob J. 2009. Original antigenic sin responses to influenza viruses. J Immunol 183: 3294-3301. doi:10.4049/jimmunol.0900398

Kim JH, Davis WG, Sambhara S, Jacob J. 2012. Strategies to alleviate original antigenic sin responses to influenza viruses. Proc Natl Acad Sci 109: 13751-13756. doi:10.1073/ pnas.0912458109

Klinman NR. 1972. The mechanism of antigenic stimulation of primary and secondary clonal precursor cells. J Exp Med 136: 241-260. doi:10.1084/jem.136.2.241

Kosik I, Yewdell JW. 2017. Influenza A virus hemagglutinin specific antibodies interfere with virion neuraminidase activity via two distinct mechanisms. Virology 500: 178-183. doi:10.1016/j.virol.2016.10.024

Kosik I, Angeletti D, Gibbs JS, Angel M, Takeda K, Kosikova M, Nair V, Hickman HD, Xie H, Brooke CB, et al. 2019. Neuraminidase inhibition contributes to influenza A virus neutralization by anti-hemagglutinin stem antibodies. J Exp Med 216: 304-316. doi:10.1084/jem.20181624

Krammer F. 2019. The human antibody response to influenza A virus infection and vaccination. Nat Rev Immunol 19: 383-397. doi:10.1038/s41577-019-0143-6
Lee J, Paparoditis P, Horton AP, Frühwirth A, McDaniel JR, Jung J, Boutz DR, Hussein DA, Tanno Y, Pappas L, et al. 2019. Persistent antibody clonotypes dominate the serum response to influenza over multiple years and repeated vaccinations. Cell Host Microbe 25: 367-376.e5. doi:10 .1016/j.chom.2019.01.010

Lewnard JA, Cobey S. 2018. Immune history and influenza vaccine effectiveness. Vaccines (Basel) 6: 28. doi:10.3390/ vaccines 6020028

Li GM, Chiu C, Wrammert J, McCausland M, Andrews SF, Zheng NY, Lee JH, Huang M, Qu X, Edupuganti S, et al. 2012. Pandemic H1N1 influenza vaccine induces a recall response in humans that favors broadly cross-reactive memory B cells. Proc Natl Acad Sci 109: 9047-9052. doi:10.1073/pnas.1118979109

Li Y, Myers JL, Bostick DL, Sullivan CB, Madara J, Linderman SL, Liu Q, Carter DM, Wrammert J, Esposito S, et al. 2013. Immune history shapes specificity of pandemic H1N1 influenza antibody responses. J Exp Med 210: 1493-1500. doi:10.1084/jem.20130212

Linderman SL, Hensley SE. 2016. Antibodies with 'original antigenic sin' properties are valuable components of secondary immune responses to influenza viruses. PLoS Pathog 12: e1005806. doi:10.1371/journal.ppat.1005806

Linderman SL, Chambers BS, Zost SJ, Parkhouse K, Li Y, Herrmann C, Ellebedy AH, Carter DM, Andrews SF, Zheng NY, et al. 2014. Potential antigenic explanation for atypical H1N1 infections among middle-aged adults during the 2013-2014 influenza season. Proc Natl Acad Sci 111: 15798-15803. doi:10.1073/pnas.1409171111

Madsen A, Azimi L, Tete S, Zhou F, Krammer F, Cox RJ, JulLarsen A. 2019. No evidence of antigenic seniority in hemagglutinin specific antibody responses after adjuvanted pandemic 2009 influenza vaccination. Vaccine: $X$ 2: 100029. doi:10.1016/j.jvacx.2019.100029

Monto AS, Malosh RE, Petrie JG, Martin ET. 2017. The doctrine of original antigenic sin: separating good from evil. J Infect Dis 215: 1782-1788. doi:10.1093/infdis/ jix173

Moody MA, Zhang R, Walter EB, Woods CW, Ginsburg GS, McClain MT, Denny TN, Chen X, Munshaw S, Marshall DJ, et al. 2011. H3N2 influenza infection elicits more cross-reactive and less clonally expanded anti-hemagglutinin antibodies than influenza vaccination. PLoS ONE 6: e25797. doi:10.1371/journal.pone.0025797

Mozdzanowska K, Furchner M, Washko G, Mozdzanowski J, Gerhard W. 1997. A pulmonary influenza virus infection in SCID mice can be cured by treatment with hemagglutinin-specific antibodies that display very low virus-neutralizing activity in vitro. J Virol 71: 4347-4355.

Noble GR, Kaye HS, Kendal AP, Dowdle WR. 1977. Agerelated heterologous antibody responses to influenza virus vaccination. J Infect Dis 136: S686-S692. doi:10.1093/ infdis/136.Supplement_3.S686

O'Donnell CD, Wright A, Vogel L, Boonnak K, Treanor JJ, Subbarao K. 2014. Humans and ferrets with prior H1N1 influenza virus infections do not exhibit evidence of original antigenic sin after infection or vaccination with the 2009 pandemic H1N1 influenza virus. Clin Vaccine Immunol 21: 737-746. doi:10.1128/CVI.00790-13

Rajendran M, Nachbagauer R, Ermler ME, Bunduc P, Amanat F, Izikson R, Cox M, Palese P, Eichelberger M, 
Krammer F. 2017. Analysis of anti-influenza virus neuraminidase antibodies in children, adults, and the elderly by ELISA and enzyme inhibition: evidence for original antigenic sin. $m$ Bio 8. doi:10.1128/mBio.02281-16

Ranjeva S, Subramanian R, Fang VJ, Leung GM, Ip DKM, Perera R, Peiris JSM, Cowling BJ, Cobey S. 2019. Agespecific differences in the dynamics of protective immunity to influenza. Nat Commun 10: 1660. doi:10.1038/ s41467-019-09652-6

Sasaki S, He X-S, Holmes TH, Dekker CL, Kemble GW, Arvin AM, Greenberg HB. 2008. Influence of prior influenza vaccination on antibody and B-cell responses. PLOS ONE 3: e2975. doi:10.1371/journal.pone.0002975

Skowronski DM, Chambers C, De Serres G, Sabaiduc S, Winter AL, Dickinson JA, Gubbay JB, Fonseca K, Drews SJ, Charest H, et al. 2017. Serial vaccination and the antigenic distance hypothesis: effects on Influenza vaccine effectiveness during $\mathrm{A}(\mathrm{H} 3 \mathrm{~N} 2)$ epidemics in Canada, 2010-2011 to 2014-2015. J Infect Dis 215: 1059-1099. doi:10.1093/infdis/jix074

Tan YC, Blum LK, Kongpachith S, Ju CH, Cai X, Lindstrom TM, Sokolove J, Robinson WH. 2014. High-throughput sequencing of natively paired antibody chains provides evidence for original antigenic sin shaping the antibody response to influenza vaccination. Clin Immunol 151: 5565. doi:10.1016/j.clim.2013.12.008

Tesini BL, Kanagaiah P, Wang J, Hahn M, Halliley JL, Chaves FA, Nguyen PQT, Nogales A, DeDiego ML, Anderson CS, et al. 2019. Broad hemagglutinin-specific memory B cell expansion by seasonal influenza virus infection reflects early-life imprinting and adaptation to the infecting virus. J Virol 93. doi:10.1128/JVI.00169-19

Vatti A, Monsalve DM, Pacheco Y, Chang C, Anaya JM, Gershwin ME. 2017. Original antigenic sin: a comprehensive review. J Autoimmun 83: 12-21. doi:10.1016/j.jaut .2017 .04 .008

Virelizier JL, Allison AC, Schild GC. 1974a. Antibody responses to antigenic determinants of influenza virus hemagglutinin: II. Original antigenic sin: a bone marrowderived lymphocyte memory phenomenon modulated by thymus-derived lymphocytes. J Exp Med 140: 1571-1578. doi:10.1084/jem.140.6.1571
Virelizier JL, Postlethwaite R, Schild GC, Allison AC. 1974b. Antibody responses to antigenic determinants of influenza virus hemagglutinin I. Thymus dependence of antibody formation and thymus independence of immunological memory. J Exp Med 140: 1559-1570. doi:10.1084/ jem.140.6.1559

Watanabe A, McCarthy KR, Kuraoka M, Schmidt AG, Adachi Y, Onodera T, Tonouchi K, Caradonna TM, Bajic G Song S, et al. 2019. Antibodies to a conserved influenza head interface epitope protect by an IgG subtype-dependent mechanism. Cell 177: 1124-1135.e16. doi:10.1016/j cell.2019.03.048

Webster RG. 1966. Original antigenic sin in ferrets: the response to sequential infections with influenza viruses. J Immunol 97: 177-183.

Webster RG, Kasel JA, Couch RB, Laver WG. 1976. Influenza virus subunit vaccines. II: immunogenicity and original antigenic sin in humans. J Infect Dis 134: 48-58. doi:10.1093/infdis/134.1.48

Wrammert J, Smith K, Miller J, Langley WA, Kokko K, Larsen C, Zheng NY, Mays I, Garman L, Helms C, et al. 2008. Rapid cloning of high-affinity human monoclonal antibodies against influenza virus. Nature 453: 667-671. doi:10.1038/nature06890

Wrammert J, Koutsonanos D, Li GM, Edupuganti S, Sui J, Morrissey M, McCausland M, Skountzou I, Hornig M, Lipkin WI, et al. 2011. Broadly cross-reactive antibodies dominate the human B cell response against 2009 pandemic H1N1 influenza virus infection. J Exp Med 208: 181-193. doi:10.1084/jem.20101352

Yewdell JW, Taylor A, Yellen A, Caton A, Gerhard W, Bachi T. 1993. Mutations in or near the fusion peptide of the influenza virus hemagglutinin affect an antigenic site in the globular region. J Virol 67: 933-942.

Zhang A, Stacey HD, Mullarkey CE, Miller MS. 2019. Original antigenic sin: how first exposure shapes lifelong anti-influenza virus immune responses. J Immunol 202: 335-340. doi:10.4049/jimmunol.1801149

Zost SJ, Wu NC, Hensley SE, Wilson IA. 2019. Immunodominance and antigenic variation of influenza virus hemagglutinin: implications for design of universal vaccine immunogens. J Infect Dis 219: S38-S45. doi:10.1093/in fdis/jiy696 


\section{$\&_{\mathrm{CSH}}^{\infty} \&$ Cold Spring Harbor

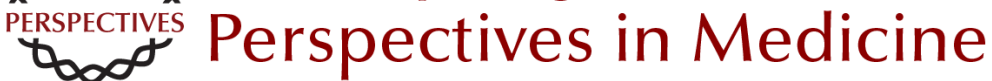

\section{Original Antigenic Sin: How Original? How Sinful?}

Jonathan W. Yewdell and Jefferson J.S. Santos

Cold Spring Harb Perspect Med 2021; doi: 10.1101/cshperspect.a038786 originally published online January 21, 2020

\section{Subject Collection Influenza: The Cutting Edge}

\section{Emerging HxNy Influenza A Viruses} William J. Liu, Yan Wu, Yuhai Bi, et al.

Equine Influenza

Thomas M. Chambers

\section{Human Influenza Epidemiology \\ Sukhyun Ryu and Benjamin J. Cowling}

Host Cell Factors That Interact with Influenza

Virus Ribonucleoproteins

Ecco Staller and Wendy S. Barclay

Induction and Evasion of Type-I Interferon

Responses during Influenza A Virus Infection

Raquel Muñoz-Moreno, Carles Martínez-Romero and Adolfo García-Sastre

Structure and Function of Influenza Polymerase Joanna M. Wandzik, Tomas Kouba and Stephen Cusack

H7N9 Influenza Virus in China Chengjun Li and Hualan Chen

H5 Influenza Viruses in Egypt Rabeh El-Shesheny, Ahmed Kandeil, Ahmed Mostafa, et al.
Antivirals Targeting the Neuraminidase Larisa Gubareva and Teena Mohan

Accessory Gene Products of Influenza A Virus Rute M. Pinto, Samantha Lycett, Eleanor Gaunt, et al.

Influenza Immunization in the Context of

Preexisting Immunity Susanne L. Linderman, Ali H. Ellebedy, Carl Davis, et al.

Hemagglutinin Structure and Activities Steven J. Gamblin, Sébastien G. Vachieri, Xiaoli Xiong, et al.

Live Attenuated Cold-Adapted Influenza Vaccines Kanta Subbarao

Next-Generation Influenza Vaccines Masaru Kanekiyo and Barney S. Graham

Selective Genome Packaging Mechanisms of Influenza A Viruses Takeshi Noda

Systems Biological Analysis of Immune Response to Influenza Vaccination Mario Cortese, Amy C. Sherman, Nadine G. Rouphael, et al.

For additional articles in this collection, see http://perspectivesinmedicine.cshlp.org/cgi/collection/ 